\title{
Uncertainty Code
}

National Cancer Institute

\section{Source}

National Cancer Institute. Uncertainty Code. NCI Thesaurus. Code C93699.

A coded value specifying whether and to what degree an entity, activity or event has been asserted to be in doubt in any way. 